
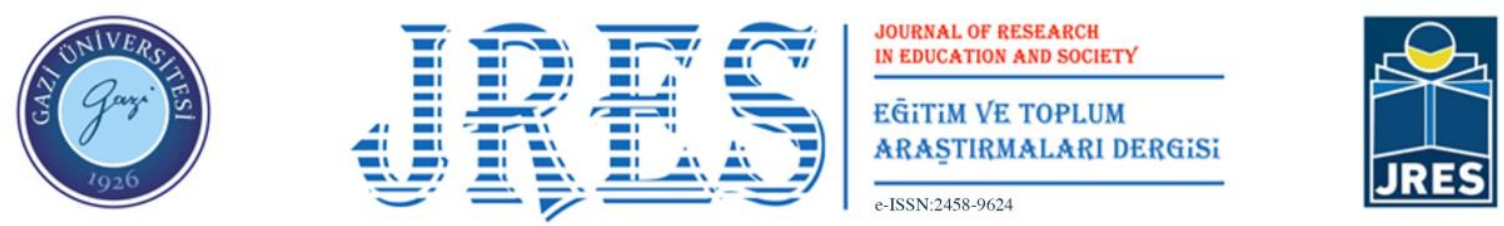

Cilt: 8 Sayı: 1 Sayfa Aralığı: 103-121 e-ISSN: 2458-9624 DOI: 10.51725/etad.875881

\title{
İlkokul ve Ortaokul Son Sınıf Öğrencilerinin İnternet Bağımlılık Düzeylerinin İncelenmesi (Adıyaman İli Örneği)*
}

\author{
A Study of Internet Addiction Levels of Primary School and Secondary School \\ Final Year Students (The Example of Adryaman Province)
}

\section{Mehmet Gültekin, Hasan Aydemir}

\section{ÖZ}

$\mathrm{Bu}$ araştırmanın amacı, ilkokul ve ortaokul son sınıf öğrencilerinin internet bağımlılık düzeylerinin incelenmesidir. İlişkisel tarama modeli kullanılmıştır. Araştırmanın evrenini 20172018 eğitim-öğretim yılında Adıyaman il merkezinde bulunan devlet okullarından; 26 ilkokuldan 4337 son sınıf öğrencisi, 28 ortaokuldan 4178 son sınıf öğrencisi olmak üzere toplamda 8515 öğrenci oluşturmaktadır. Araştırmanın örneklemini evrende bulunan okullar içerisinde tesadüfi olarak seçilmiş; 26 ilkokuldan 1923 son sınıf öğrencisi, 28 ortaokuldan 1756 son sınıf öğrencisi olmak üzere toplamda 3679 öğrenci oluşturmaktadır. Ulaşılan 3679 öğrenciden 2808 tanesi

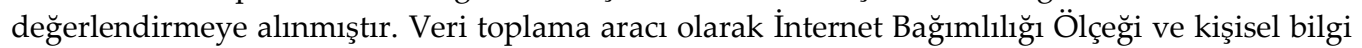
formu kullanılmıştır. Veriler, tek yönlü varyans analizi (One Way Anova) testi, iki aşamalı küme metodu (Twostep Cluster), t-testi ile analiz edilmiştir. Değerlendirmeye alınan 2808 öğrenci içerisinden 272'si (\% 9.7) bağımlı grupta, 553’ü (\% 19.7) bağımlılık riski taşıyan grupta, 796'sı (\% 28.3) eşik grubunda, 1187'si (\% 42.3) bağımlı olmayan grupta yer aldığı bulunmuştur.

\section{ABSTRACT}

The purpose of this study is to investigate the internet addiction levels of primary school and secondary school's last year students. The relational screening method was used. The population of this study is composed of 4337 senior students from 26 public primary schools and 4178 senior students from 28 public secondary schools of Adiyaman province in academic year of 2017-2018, in total 8515 students. The sample of the research consists of 1923 senior students from 26 primary schools and 1756 senior students selected from 28 secondary schools which were selected randomly from the schools in population. Of the 3679 students, 2808 were taken into consideration. Internet Addiction Scale and personal information form were used as data collection tools. Data were analyzed by one-way analysis of variance (One Way Anova) test, twostage cluster method (Twostep Cluster), t-test. It was found that, of the 2808 students who were evaluated, $272(\% 9.7)$ are in the addiction group, that $553(\% 19.7)$ are in the addiction risk group, that $796(\% 28.3)$ are in the threshold group, and that $1187(\% 42.3)$ are in the non-addicted group.

Yazar Bilgileri Mehmet Gültekin iD

Öğretmen, Cumhuriyet İlkokulu, Adıyaman, Türkiye mehmet gultekin02@hotmail.com

Hasan Aydemir (iD)

Doç. Dr., İnönü Üniversitesi,

Eğitim Fakültesi, Temel

Eğitim Bölümü, Malatya,

Türkiye

hasan.aydemir@inonu.edu.tr

\begin{tabular}{r} 
Makale Bilgileri \\
\hline Anahtar Kelimeler \\
Bağımlılı \\
İnternet \\
Internet bağımlılı̆̆1 \\
Keywords \\
Addiction \\
Internet \\
Internet addiction \\
Makale Geçmişi \\
Geliş: 07/02/2021 \\
Düzeltme: 03/05/2021 \\
Kabul: 04/05/2021
\end{tabular}

Makale Bilgileri

Bă̆ımlılık

nternet

g1

\section{n}

nternet

ion 


\section{Giriş}

\section{Problem Durumu}

Küreselleşen dünyada yenilenen ve gelişen teknolojiyle bilgiye erişim kolaylaşmıştır. Bilişim teknolojilerinde görülen gelişmeler sayesinde insanlar istedikleri bilgiye, istedikleri zaman ve istedikleri yerden kolayca ulaşabilir hale gelmiştir. Bu şekildeki hızlı gelişmeler sağlık, eğitim, sanayi, ticaret gibi birçok alanda internet kullanımının yaygınlaşmasına ve insanların internete olan bağlılığının da artmasına neden olmuştur. Bunun sonucunda ise internet insanların günlük hayatının önemli bir parçası haline gelmeye başlamıştır (Gençer, 2011, s. 5).

İlk insanlardan günümüze kadar insanlar birbirleri ile iletişim içerisinde olmuşlardır. İnsanın sosyal bir varlık olmasından dolayı iletişim gereksinimi sürekli katlanarak artmıştır. İnsanların birbirleriyle yüz yüze mesaj alışverişinde bulunması olarak tanımlanan iletişim kavramı, günümüz bilgi çağında iletişim kavramı artık insanların kıtalar arasında bile kolaylıkla haberleşme sağlayabildiği evrensel bir boyuta taşınmıştır (Doğruluk, 2017, s. 1). Milattan sonra 1400'lü yıllarda yazılı basım ve haberleşmenin gelişmesine sebep olan matbaa bulunmuş ve yirminci yüzyılda televizyonun ve radyonun keşfedilmesiyle de geniş kitlelere erişmek daha da hızlanmıştır. Son çeyrek asırda da teknoloji daha çok hızlanmış bilgisayar ve internet keşfedilerek iletişimi sağlayan yeni araçlar olarak kullanılmaya başlanmıştır (Koçaş, 2017, s. 25). Dünya' daki büyük değişimler, büyük kolaylıkları insan hayatına katmış ve uyum sorunlarını da beraberinde getirmiştir. Enformasyon devrimi de kolaylıklar ve uyum sorunlarını ortaya çıarmıştır. Bu çağın büyük keşfi internet dünyanın tamamını kuşatmış ve birbirinden farklı kültürlerde yaşayan insanların internetle ilgili davranışları neredeyse benzeşmiştir. İnternet ile alakalı bireyler benzer alışkanlık ve davranışlar sergilemeye başlamışlardır (Bayraktar, 2013, s. 3).

Temelleri Amerika'da atılmış olan internet, teknolojinin hızlı bir şekilde ilerlemesiyle bütün dünyayı etkisi altına almıştır. İçinde bulunulan teknolojik devirde kullanılan bilgisayarlar ile internet insanoğlunun vazgeçilmezi olmuştur. İnternetin hızlı bir şekilde yayılıp bütün dünyayı etkilemesi birçok disiplin tarafından incelenmiş ve psikoloji literatüründe de internetin bireylerin üzerindeki etkisi konusunda ele alınmaktadır (Aksoy, 2016, s. 1).

İnternet, dünya üzerindeki bilgisayar sistemlerini birbirine bağlamaktadır. İnternet her geçen gün yaygınlaşmakta, sürekli yenilenen gelişen herkes için iletişim ve bilgi paylaşım aracıdır. Ülkemizde de internet kullanımı giderek yaygınlaşmaktadır (Saatçığlu, 2016, s. 11). Türkiye'de ise internetin ilk kullanılmaya başlamasıyla birlikte önemli gelişimler, değişimler yaşanmıştır. Türkiye İstatistik Kurumu'nun (TÜIK) 2018 yılı ağustos ayı verilerine göre Türkiye'de 55 milyonun üzerinde internet kullanıcısı bulunmaktadır. 16-74 yaş arası kullanıcılara bakıldığında ise nüfusun \%72.9'ubilgisayar ve internet kullanıcısıdır (TÜIK, 2018). Social (2018) “Global Dijital İstatistikler" verilerine göre de dijital dünya muazzam bir büyüme yaşamaktadır. Günümüzde 4,02 milyarı bulan küresel internet kullanıcısının olduğunu ve dünya nüfusunun \%53'lük kısmının internete eriştiğini görmekteyiz. Bu nüfusun 3.1 milyarı aktif olarak sosyal medya kullanmaktadır. Kullanıcıların 2.9 milyarı sosyal medyaya mobilden bağlanırken, toplam mobil kullanıcı sayısı ise 5.1 milyardır. Ayrıca dünya genelinde 1.8 milyar kişi e-ticaret kullanıcısıdır. Bu rakamlara göre birçok kişinin bir türlü (alışveriş, bankacılık işlemleri, tanıtım, seyahat, eğitim, sağlık gibi) internete girdiği görülebilmektedir.

Dünyayı saran internet, yaygınlaşmış ve herkes tarafından ulaşılabilir hale gelmiştir. Bu yayılma sonucunda birtakım olumsuzluklar meydana gelmiştir. Bu olumsuzlukların bir tanesi de internet bağımlılı̆̆ıdır (Ceyhan, 2016, s. 4). İnternet evde ve iş yerlerinde günlük hayatımızı değiştirecek 
önemli bir iletişim aracıdır. Günümüz yeni teknolojisi ile birlikte, iyi veya kötü isimlendirebileceğimiz, çeşitli insan davranışları ortaya çıkmıştır. Bu yüzden de bazı internet kullanıcılarının "İnternet Bağımlılığı" olarak isimlendirilen sorunlu davranışları var olmuştur (Yellowlees ve Marks, 2007, s. 1452). İnsanların ihtiyaç duyduğu bilgiye ulaşmalarına yardımcı olan eğlenceli ve hoşça vakit geçirmelerine ve sevdikleriyle iletişimde bulunabilmelerine imkân tanıyan kitle iletişim aracıdır. Fakat internetin getirdiği bu kolaylıkların yanında çok kullanmaktan kaynaklanan bazı sorunlara da yol açmaktadır. Söz konusu sorunların başında da internet bağımlılığı gelmektedir (Balcı ve Gülnar, 2009, s. 5).

İnternet bağımlılığı hakkında yapılan çeşitli araştırmalara göre ise internet bağımlılı̆̆ı gösterenlerin birçoğunda farklı psikiyatrik rahatsızlıkların olduğu ve psikolojik, sosyal, fiziksel sorunlar ve ailesel problemler internet bağımlılı̆̆ı ile birlikte ortaya çıkabilmektedir (Sağat, 2017, s. 16). Young (1996) ise yaptığı çalışmada alkolün, kumarın ve uyuşturucu bağımlılığının, akademik başarısızlıkla sonuçlandığını, internet bağımlılığının da akademik başarısızlıkla sonuçlanabileceğini belirtmiştir. Chen, Tarn ve Han (2004) ise internet bağımlılığının alkol bağımlılığına benzer şekilde insanların kendilerini maddenin etkisine maruz bırakması gibi olduğunu belirtmişlerdir (s. 50).

Alan yazın incelendiğinde ise araştırmacılar, kişilerin internet bağımlısı olup olmadıklarının ölçülmesi ile ilgili farklı ölçüm tekniklerini kullandıkları görülmektedir. Bu noktada, Young (1996) geliştirdiği internet bağımlılık kriterlerinden sekiz tanesinden beş tanesi bireyde mevcutsa internet bağımlısı olduğunu kabul etmiştir (s. 239). Brenner (1997) “İnternetle İlgili Bağımlı Davranış Envanteri (Internet Related Addictive Behavior Inventory)" adında 32 maddelik, doğru-yanlış olarak yanıtlanabilecek bir ölçek geliştirmiştir. Chen ve Chou (1999) Çin'de internet bağımlılığı ile ilgili 28 maddeden oluşan ölçek geliştirmişlerdir. Morahan-Martin ve Schumacher (2000) araştırmalarında 13 maddelik araçtan dört ve fazlasını işaretleyenleri internet bağımlısı olarak kabul etmişlerdir (aktaran Çakır, Horzum ve Ayas, 2013, s. 7).

Teknolojinin gelişmesiyle kullanımı gittikçe yaygınlaşan ve sosyal hayatı önemli derecede etkileyen internetin bilinçsiz kullanımı bireysel ve toplumsal hayata yönelik tehditler sunmaktadır. $\mathrm{Bu}$ nedenle son yıllarda bireylerde; aşırı internet kullanımı, internette geçirilen zamanı kontrol edememe, internete ulaşımın kısıtlanması durumunda endişe duyma, internette geçirilen zamanı yönetme güçlügü, depresyon, yalnızlık, toplumla ve aile bireyleriyle sosyal etkileşimi azaltma, sinirsel ve psikolojik sorunlar görülmektedir. İnternet kullanımında ortaya çıkan bu sorunlar, bireylerin akademik, finansal, ailevi ve meslek hayatlarını olumsuz etkilemeleri nedenleriyle "problemli" olarak tanımlanmaktadır (Reisoğlu, Gedik ve Göktaş, 2013, s. 152). Batıgün ve Hasta (2010) ise internet bağımlısı olduğunu varsayacağımız kişilerin sosyal ilişkilerinin azaldığı kişilerarası ilişkilerde sorunlar yaşadıkları, interneti aşırı derecede kullanan kişilerin aileleri ve arkadaşları ile daha az etkileşimde bulundukları ve onlara daha az zaman ayırdıklarını belirtmişlerdir (s. 214).

Bağımlılık ciddi bir hastalıktır. Bağımlılığa ilişkin beyinde birçok nörokimyasal, nörofizyolojik değişimler saptanmıştır. Bağımlılık tedavisi, belirli şemaları ve ilkeleri içeren kapsamlı bir protokol ile sağlanabilir. Bağımlı kişiler bağımlılığın bir hastalık olduğunu kabul eder ve hastalıklarda uyulması gereken kurallar olduğunu bilirlerse tedaviye uyumları artmaktadır (Yeşilay, 2017). İnternet bağımlılığı ise öğrencilerin yaşamı üzerinde eğitimsel, fiziksel ve zihinsel etkiye sahip öğrenciler arasında ortaya çıkan bir sorun haline gelmiştir. Bu nedenle, internetin güvenli ve sağlıklı kullanımı için gerekli olan internet bağımlılığının önlenmesinin önemini anlamak gerekir (Ganesh vd., 2017, s. 10). İnternetin bilgiye erişim ve bilginin paylaşımındaki öneminin gittikçe arttığı günümüzde, öğrenciler üzerinde olumlu etkilerinin yanı sıra olumsuz etkilerinin de hızla artıyor olması, internet bağımlılık düzeyinin 
tespiti hakkındaki araştırmaların yapılması zorunluluğunu doğurmuştur. Ayrıca internet bağımlılığı, üzerinde çalışılması gereken önemli bir sorun olabilir. Bu sorunun nedenlerini tespit etmek için ilkokul ve ortaokul son sınıf öğrencilerinin internet bağımlılık düzeyi incelenmiştir.

\section{Araştırmanın Amacı}

Teknoloji dünyada çok hızlı biçimde ilerlemektedir. İnternet de bu ilerlemede öncülük etmektedir. İnternetin bu hızlı yayılması ve çok fazla amaç için kullanılması bireylerin olumsuz etkilenmesine neden olmaktadır. Bireylerin internete bağımlı hale gelmeleri birtakım sorunlara neden olabileceği için "İnternet Bağımlılığı" problem olarak görülebilmektedir. Bu çalışmayla, Adıyaman il merkezinde bulunan ilkokul ve ortaokul son sınıf öğrencilerinin internet bağımlılık düzeylerinin çeşitli değişkenler açısından araştırılması amaçlanmaktadır.

\section{Araştırma Problemi}

Araştırmamın problem cümlesi, “ilkokul ve ortaokul son sınıf öğrencilerinin internet bağımlılık düzeylerinin çeşitli değişkenler ile ilişkisi nedir?" olarak belirlenmiştir.

\section{Araştırmanın Alt Problemleri}

1. İlkokul ve ortaokul son sınıf öğrencilerinin, internet bağımlılık düzeyleri arasında farklılaşma var midır?

2. İlkokul ve ortaokul son sınıf öğrencilerinin, öğrenim gördügü okul kademelerine göre internet bağımlılık düzeyleri farklılaşmakta mıdır?

3. İlkokul ve ortaokul son sınıf öğrencilerinin, internet bağımlılık düzeyleri cinsiyetlerine göre farklılaşmakta mıdır?

4. İlkokul ve ortaokul son sınıf öğrencilerinin, internet bağımlılık düzeyleri anne eğitim durumlarına göre farklılaşmakta mıdır?

5. İlkokul ve ortaokul son sınıf öğrencilerinin, internet bağımlılık düzeyleri baba eğitim durumlarına göre farklılaşmakta mıdır?

6. İlkokul ve ortaokul son sınıf öğrencilerinin, internet bağımlılık düzeyleri anne mesleklerine göre farklılaşmakta mıdır?

7. İlkokul ve ortaokul son sınıf öğrencilerinin, internet bağımlılık düzeyleri baba mesleklerine göre farklılaşmakta mıdır?

8. İlkokul ve ortaokul son sınıf öğrencilerinin, internet bağımlılık düzeyleri aile aylık gelir durumuna göre farklılaşmakta mıdır?

9. İlkokul ve ortaokul son sınıf öğrencilerinin, internet bağımlılık düzeyleri ile ilgilendiği bir spor dalı arasında farklılaşma var mıdır?

10. İlkokul ve ortaokul son sınıf öğrencilerinin, internet bağımlılık düzeyleri ile ilgilendiği bir müzik dalı arasında farklılaşma var mıdır?

\section{Araştırmanın Önemi}

İnternet günlük hayatın her alanında kullanılan ve vazgeçilemez bir teknolojidir. Fakat son yıllarda internet özellikle öğrenciler arasında bilinçli ve verimli olarak kullanılmamaktadır. İnternetin bilinçli ve verimli olarak kullanılmaması "İnternet Bağımlılı̆̆ı" olarak ifade edilen yeni bir sorunun 
ortaya çıkmasına sebep olmuştur (Doğruluk, 2017, s. 2). Arısoy (2009) da internetin ortaya çıkış amacının iletişimi arttırmak ve bilgi paylaşımını kolaylaştırmak olmasına rağmen internetin tahmin edilenden de hızlı yaygınlaşması patolojik aşırı kullanıma ve yeni bir bağımlılık türü olarak nitelenebilecek internet bağımlılığına yol açmaya başladığını ifade etmiştir. İnternetin bilgiye erişim ve bilginin paylaşımındaki öneminin gittikçe arttığı günümüzde, gençler üzerindeki olumlu etkilerinin yanı sıra olumsuz etkilerinin de hızla artıyor olması, problemli internet kullanımı hakkındaki araştırmaların yapılması zorunluluğunu doğurmuştur (Öztürk ve Kaymak-Özmen, 2011, s. 1796). Alan yazın incelendiğinde de araştırmacılar internetin amacı dışında ve aşırı kullanımını bağımlılık olarak nitelendirmektedirler.

Türkiye'nin, genç nüfusunun fazla olması gelişmekte olan ülke olması internet kullanımının giderek yaygınlaşması işsizlik ve internet kafelerin kontrolsüzce çoğalması tablet ve akıllı telefon kullanımının yaygınlaşması nedeniyle internet bağımlılığı olarak tanımlanan bozukluk için uygun bir zemin oluşturmaktadır. Türkiye'de internet bağımlılı̆̆ı problemi teknolojiye hâkim olan gençlerde ve çocuklarda daha fazla görülmektedir. Aileler de çocuklarının internet kullanımının yol açtığı sorunlar nedeniyle internet bağımlılığının tedavisini yapabilecek sağlık merkezleri arayışına girmeye başlamıştır. Gençlerde ve çocuklardaki internet bağımlılığının farkına varılması son derece önemlidir ancak internet bağımlılığını önlemeye yönelik sağlıklı ve uygulanabilir planların yapılması ile mümkün olabilecektir. Bu araştırmanın eğitim paydaşlarına, araştırmacılara ve internet bağımlılık probleminin giderilmesine katkı sağlayacağı düşünülmektedir.

\section{Yöntem}

\section{Araştırma Grubu}

Araştırmanın evrenini, 2017-2018 eğitim-öğretim yılında Adıyaman il merkezinde bulunan devlet okullarından; yirmi altı ilkokuldan 4337 son sını öğrencisi, yirmi sekiz ortaokuldan 4178 son sınıf öğrencisi olmak üzere toplamda 8515 öğrenci oluşturmaktadır. Araştırmanın örneklemini, yirmi altı ilkokuldan 1923 son sınıf öğrencisi, yirmi sekiz ortaokuldan 1756 son sınıf öğrencisi olmak üzere toplamda 3679 öğrenci oluşturmaktadır. Ulaşılan 3679 öğrenciden, ilkokul son sınıf öğrencilerinin 1479 'u, ortaokul son sınıf öğrencilerinin $1329^{\prime}$ u olmak üzere toplam 2808 'i değerlendirmeye alınmıştır. Örneklemin 2808 öğrenciden oluşturulmasının sebebi, araştırmayı daha geniş kitlelere genelleyebilmektir. Örnekleme ait demografik özellikler Tablo 1'de gösterilmiştir.

Tablo 1. Öğrencilerin Demografik Özellikleri

\begin{tabular}{llcc}
\hline Değişken & Seçenekler & Frekans (f) & Yüzde (\%) \\
\hline \multirow{3}{*}{ Cinsiyet } & Kiz & 1348 & 48 \\
& Erkek & 1460 & 52 \\
& Toplam & 2808 & 100.0 \\
\hline & Okur-Yazar & 292 & 10.4 \\
& Ilkokul & 851 & 30.3 \\
\multirow{4}{*}{ Anne Eğitim Durumu } & Ortaokul & 684 & 24.4 \\
& Lise & 548 & 19.5 \\
& Üniversite & 352 & 12.5 \\
& Lisans Üstü & 81 & 2.9 \\
& Toplam & 2808 & 100.0 \\
\hline & Okur-Yazar & 196 & 7 \\
& İlkokul & 416 & 14.8 \\
& Ortaokul & 582 & 20.7 \\
Baba Eğitim Durumu & Lise & 756 & 27 \\
& Üniversite & 680 & 24.2 \\
& Lisans Üstü & 178 & 6.3 \\
& Toplam & 2808 & 100.0 \\
\hline
\end{tabular}




\begin{tabular}{|c|c|c|c|}
\hline \multirow{5}{*}{ Anne Mesleği } & Ev Hanımı & 2293 & 81.7 \\
\hline & Serbest Meslek & 174 & 6.2 \\
\hline & İşçi & 40 & 1.4 \\
\hline & Memur & 301 & 10.7 \\
\hline & Toplam & 2808 & 100.0 \\
\hline \multirow{6}{*}{ Baba Mesleği } & Serbest Meslek & 1624 & 57.8 \\
\hline & Memur & 751 & 26.7 \\
\hline & İşçi & 218 & 7.8 \\
\hline & Çiftçi & 109 & 3.9 \\
\hline & Emekli & 106 & 3.8 \\
\hline & Toplam & 2808 & 100.0 \\
\hline \multirow{5}{*}{ Ailenin Aylık Geliri } & 1500 TL ve Altı & 1327 & 47.3 \\
\hline & $1501-3000 \mathrm{TL}$ & 618 & 22 \\
\hline & $3001-4500 \mathrm{TL}$ & 298 & 10.6 \\
\hline & 4501 TL ve Üstü & 565 & 20.1 \\
\hline & Toplam & 2808 & 100.0 \\
\hline \multirow{3}{*}{$\begin{array}{l}\text { Herhangi bir spor dalı ile } \\
\text { ilgileniyor musunuz? }\end{array}$} & Evet & 1867 & 66.5 \\
\hline & Hayır & 941 & 33.5 \\
\hline & Toplam & 2808 & 100.0 \\
\hline \multirow{3}{*}{$\begin{array}{l}\text { Herhangi bir müzik aleti } \\
\text { çalıyor musunuz? }\end{array}$} & Evet & 1023 & 36.4 \\
\hline & Hayır & 1785 & 63.6 \\
\hline & Toplam & 2808 & 100.0 \\
\hline
\end{tabular}

Tablo 1 incelendiğinde, örneklem grubunu oluşturan öğrencilerin \%48'i K1z, \%52'si Erkeklerden oluşmaktadır. Anne eğitim durumuna göre; Okur-Yazar \%10.4, İlkokul \%30.3, Ortaokul \%24.4, Lise \%19.5, Üniversite \%12.5 ve Lisans Üstü \%2.9 olarak bulunmuştur. Baba eğitim durumuna göre; Okur-Yazar \%7, İlkokul \%14.8, Ortaokul \%20.7, Lise \%27, Üniversite \%24.2 ve Lisans Üstü \%6.3 olarak bulunmuştur. Anne mesleği; Ev Hanımı \%81.7, Serbest Meslek \%6.2, İşçi \%1.4 ve Memur olanlar \%10.7 olarak bulunmuştur. Baba mesleği; Serbest Meslek \%57.8, Memur \%26.7, İşçi \%7.8, Çiftçi \%3.9 ve Emekli olanlar \%3.8 olarak bulunmuştur. Aylık gelir düzeyinde, "1500 TL ve Altı" \%47.3, "1501 TL 3000 TL” \%22, “3001 TL - 4500 TL” \%10.6 ve “4501 TL ve Üstü” \%20.1 olarak bulunmuştur. Öğrencilerin herhangi bir spor yapma durumu, evet \%66.5 ve hayır \%33.5 olarak bulunmuştur. Öğrencilerin bir müzik aleti çalma durumu, evet \%36.4 ve hayır \%63.6 olarak bulunmuştur.

\section{Etik Bildirim}

Bu araştırma, 01.01.2020 tarihinden önce yapıldığından etik kurul kararı zorunluluğu yoktur.

\section{Verilerin Toplanmasi}

Araştırmada, ilkokul ve ortaokul son sınıf öğrencilerinin internet bağımlılık düzeylerini tespit etmek amacıyla Demografik Bilgi Formu ve Günüç (2009) tarafından geliştirilen “İnternet Bağımlılığı Ölçeği” kullanılmıştır. İnternet Bağımlılı̆̆ı Ölçeği, dört temel boyutu olan ve bu dört temel boyutun 35 maddelik alt boyutundan oluşan bir ölçektir. Ölçek; internet bağımlılığına yönelik olarak "Yoksunluk", "Kontrol Güçlüğü", "İşlevsellikte Bozulma" ve "Sosyal İzolasyon" olarak dört temel boyutu ölçmektedir. Ölçeğin Cronbach alfa $(\alpha)$ iç tutarlık katsayısı 944 bulunmuştur.

\section{Verilerin Analizi}

Veriler bilgisayara aktarılarak SPSS (The Statistical Package for Social Sciences) 17.0 paket programı kullanılarak analiz edilmiştir. Verilerin analizinde frekans, $\mathrm{t}$ testi, yüzde (\%), aritmetik ortalama, tek yönlü varyans analizi (ANOVA) testi ve iki aşamalı küme metodu (Twostep Cluster) istatistiksel teknikler kullanılmıştır. Kümeleme analizi grupları, birbiriyle benzer alt kümelere ayırmaya yardımcı olan, çok değişkenli istatistiksel analiz yöntemlerinden biridir. Dinçer'e (2006, s. 24) göre kümeleme analizi, bir veri kümesindeki bilgileri belirli yakınlık kriterlerine göre gruplara ayırma işlemidir. Bu grupların her birine "küme", kümeleme analizine ise "kümeleme" olarak ifade etmiştir. 
Öğrencilerin internet bağımlılık düzeylerini belirlenmesinde detaylı analiz sonuçları elde etmek için hiyerarşik olmayan küme yöntemlerinden "İki Aşamalı Kümeleme Yöntemi (Twostep Cluster)" uygulanmıştır. İki aşamalı kümeleme yöntemi Ward'ın minimum varyans yöntemi ile kmeans (kortalama) yöntemlerinin birleştirilmesi ile oluşan hibrid (melez) kümeleme tekniğidir (Savaş ve Topaloğlu, 2011, s. 247). İki aşamalı kümeleme yöntemi, diğer kümeleme yöntemleri ile kıyaslandığında hem sürekli hem de kategorik verileri işleyebilme özelliğine sahiptir. Ayrıca büyük örneklem büyüklüklerinde esnek olması nedeniyle tercih edilmektedir (Ceylan, Gürsev ve Bulkan, 2017).

\section{Bulgular}

\section{Öğrencilerin İnternet Bağımlılık Düzeylerine İlişkin Bulgular ve Yorum}

Katılımcıların internet bağımlılığı hakkında daha detaylı bulgular elde etmek için kümeleme analizi yöntemi kullanılmıştır. İki aşamalı kümeleme yöntemi kullanılırken araştırmadaki kümelerin isimlendirilmesinde Günüç’ün (2009) araştırması örnek alınmıştır. Birinci kümede "bağımlı grup", ikinci kümede "risk grubu", üçüncü kümede "eşik grubu (bağımlı olma ya da olmama durumunda bir eğilimi bulunmayan)" ve dördüncü kümede "bağımlı olmayan grup" yer almıştır. İki aşamalı kümeleme analizi sonuçları Tablo 2'de gösterilmiştir.

Tablo 2. İki Aşamalı Kümeleme Analizi (TwoStep Cluster Analysis)

\begin{tabular}{lcccc}
\hline Kümeleme (Cluster) & $\mathbf{N}$ & $\overline{\mathbf{X}}$ & Birleşik (\%) & Toplam (\%) \\
\hline 1 (Bağımlı Grup) & 272 & 3.75 & 9.7 & 9.7 \\
2 (Risk Grubu) & 553 & 2.70 & 19.7 & 19.7 \\
3 (Eşik Grubu) & 796 & 2.03 & 28.3 & 28.3 \\
4 (Bağımlı Olmayan Grup) & 1187 & 1.38 & 42.3 & 42.3 \\
\hline Toplam & 2808 & & 100 & 100 \\
\hline
\end{tabular}

Tablo 2 incelendiğinde, birinci küme \%9.7 “Bağımlı Grup", ikinci küme \%19.7 “Bağımlılık Riski Taşıyan Grup", üçüncü küme \%28.3 "Eşik Grubu" (bağımlı olma ya da olmama durumunda bir eğilimi bulunmayan), dördüncü küme ise \%42.3 "Bağımlı Olmayan Grup” yer almaktadır. Çıkan sonuçlar dikkate alındığında değerlendirmeye alınan bireylerin büyük çoğunluğu \%42.3 ile bağımlı olmayan grupta yer almiştır.

Tablo 3. İlkokul Son Sınıf Öğrencilerinin İnternet Bağımlılık Düzeylerine İlişkin Bulgular

\begin{tabular}{lcccc}
\hline Kümeleme (Cluster) & $\mathbf{N}$ & $\overline{\mathbf{X}}$ & Birleşik (\%) & Toplam (\%) \\
\hline $\mathbf{1}$ (Bağımlı Grup) & 137 & 3.79 & 9.3 & 9.3 \\
2 (Risk Grubu) & 258 & 2.77 & 17.4 & 17.4 \\
3 (Eşik Grubu) & 414 & 2.05 & 28.0 & 28.0 \\
4 (Bağımlı Olmayan Grup) & 670 & 1.40 & 45.3 & 45.3 \\
\hline Toplam & 1479 & & 100 & 100 \\
\hline
\end{tabular}

Tablo 3 incelendiğinde, birinci küme \%9.3 "Bağımlı Grup", ikinci küme \%17.4 "Bağımlılık Riski Taşıyan Grup", üçüncü küme \%28 “Eşik Grubu”, dördüncü küme ise \%45.3 "Bağımlı Olmayan Grup" yer almaktadır. Çıkan sonuçlar dikkate alındığında ilkokul son sınıf öğrencilerinden değerlendirmeye alınanların büyük çoğunluğu \%45.3 ile bağımlı olmayan grupta yer almıştır. 
Tablo 4. Ortaokul Son Sınıf Öğrencilerinin İnternet Bağımlılık Düzeylerine İlişkin Bulgular

\begin{tabular}{lcccc}
\hline Kümeleme (Cluster) & $\mathbf{N}$ & $\overline{\mathbf{x}}$ & Birleşik (\%) & Toplam (\%) \\
\hline 1 (Bağımlı Grup) & 123 & 3.72 & 9.4 & 9.4 \\
2 (Risk Grubu) & 247 & 2.73 & 18.6 & 18.6 \\
3 (Eşik Grubu) & 425 & 2.01 & 31.9 & 31.9 \\
4 (Bağımlı Olmayan Grup) & 534 & 1.37 & 40.1 & 40.1 \\
\hline Toplam & 1329 & & 100 & 100 \\
\hline
\end{tabular}

Tablo 4 incelendiğinde, birinci küme \%9.4 “Bağımlı Grup", ikinci küme \%18.6 “Bağımlılık Riski Taşıyan Grup", üçüncü küme \%31.9 “Eşik Grubu”, dördüncü küme ise \%40.1 “Bağımlı Olmayan Grup” yer almaktadır. Çıkan sonuçlar dikkate alındığında ortaokul son sınıf öğrencilerinden değerlendirmeye alınanların büyük çoğunluğu \%40.1 ile bağımlı olmayan grupta yer almıştır.

\section{Öğrencilerin Öğrenim Gördüğü Okul Kademesine İlişkin Bulgular}

Öğrencilerin öğrenim gördüğü okul kademelerine göre internet bağımlılık puanları arasında anlamlı farklılaşmanın olup olmadığını belirlemek için $t$ testi yapılmış olup, sonuçlar Tablo 5 'te gösterilmiştir.

Tablo 5. İnternet Bağımlılık Düzeyinin Öğrenim Gördüğü Okul Kademesine Göre İlişkisi

\begin{tabular}{|c|c|c|c|c|c|c|c|}
\hline Boyutlar & Okul Kademesi & $\mathbf{N}$ & $\overline{\mathbf{x}}$ & SS & sd & $t$ & $p$ \\
\hline \multirow{2}{*}{ 1- Yoksunluk } & İlkokul & 1479 & 2.37 & 0.90 & \multirow{2}{*}{2806} & \multirow{2}{*}{-6.52} & \multirow{2}{*}{$.000^{*}$} \\
\hline & Ortaokul & 1329 & 2.59 & 0.90 & & & \\
\hline \multirow{2}{*}{ 2- Kontrol Güçlüğ̈̈ü } & İlkokul & 1479 & 1.97 & 0.89 & \multirow{2}{*}{2806} & \multirow{2}{*}{-3.69} & \multirow{2}{*}{$.000^{*}$} \\
\hline & Ortaokul & 1329 & 2.09 & 0.84 & & & \\
\hline \multirow{2}{*}{$\begin{array}{l}\text { 3- İşlevsellikte } \\
\text { Bozulma }\end{array}$} & İlkokul & 1479 & 1.93 & 0.91 & \multirow{2}{*}{2806} & \multirow{2}{*}{.72} & \multirow{2}{*}{.469} \\
\hline & Ortaokul & 1329 & 1.91 & 0.87 & & & \\
\hline \multirow{2}{*}{ 4- Sosyal İzolasyon } & İlkokul & 1479 & 1.91 & 0.89 & \multirow{2}{*}{2806} & \multirow{2}{*}{5.88} & \multirow{2}{*}{$.000^{*}$} \\
\hline & Ortaokul & 1329 & 1.72 & 0.78 & & & \\
\hline 5- İnternet Bağımlılık & İlkokul & 1479 & 2.04 & 0.78 & \multirow{2}{*}{2806} & \multirow{2}{*}{-1.14} & \multirow{2}{*}{.252} \\
\hline Ölçeği (Genel) & Ortaokul & 1329 & 2.08 & 0.73 & & & \\
\hline
\end{tabular}

$N=2808$

Tablo 5 incelendiğinde, ilkokul ve ortaokul son sınıf öğrencilerinin internet bağımlılı̆̆ ölçeğinin boyutlarından işlevsellikte bozulma boyutunda ve internet bağımlılık ölçeğinin genelinde anlamlı farklılaşma görülmemektedir ( $p>0.05$ ). Yoksunluk, kontrol güçlüğü ve sosyal izolasyon boyutlarında okul kademelerine göre anlamlı bir farklılaşma görülmektedir $(\mathrm{p}<0.05)$.

\section{Öğrencilerin Cinsiyet Değişkenine İlişkin Bulgular}

Tablo 6. İnternet Bağımlılık Düzeyinin Cinsiyet Değişkeni ile İlişkisi

\begin{tabular}{|c|c|c|c|c|c|c|c|}
\hline Boyutlar & Cinsiyet & $\mathbf{N}$ & $\overline{\mathbf{x}}$ & SS & $s d$ & $t$ & $p$ \\
\hline \multirow{2}{*}{ 1- Yoksunluk } & Kiz & 1348 & 2.38 & 0.88 & \multirow{2}{*}{2806} & \multirow{2}{*}{-5.37} & \multirow{2}{*}{$.000^{*}$} \\
\hline & Erkek & 1460 & 2.56 & 0.93 & & & \\
\hline \multirow{2}{*}{ 2- Kontrol Güçlüğ̈̈ } & Kiz & 1348 & 1.95 & 0.81 & \multirow{2}{*}{2806} & \multirow{2}{*}{-4.68} & \multirow{2}{*}{$.000^{*}$} \\
\hline & Erkek & 1460 & 2.10 & 0.91 & & & \\
\hline \multirow{2}{*}{ 3- İşlevsellikte Bozulma } & Kiz & 1348 & 1.82 & 0.82 & \multirow{2}{*}{2806} & \multirow{2}{*}{-5.54} & \multirow{2}{*}{$.000^{*}$} \\
\hline & Erkek & 1460 & 2.01 & 0.94 & & & \\
\hline \multirow{2}{*}{ 4- Sosyal İzolasyon } & $\mathrm{K} 1 \mathrm{z}$ & 1348 & 1.71 & 0.76 & \multirow{2}{*}{2806} & \multirow{2}{*}{-6.53} & \multirow{2}{*}{$.000^{*}$} \\
\hline & Erkek & 1460 & 1.92 & 0.91 & & & \\
\hline 5- İnternet Bağımlılık & Kiz & 1348 & 1.96 & 0.69 & \multirow{2}{*}{2806} & \multirow{2}{*}{-6.43} & \multirow{2}{*}{$.000^{*}$} \\
\hline Ölçeği (Genel) & Erkek & 1460 & 2.15 & 0.80 & & & \\
\hline
\end{tabular}


Tablo 6 incelendiğinde, ilkokul ve ortaokul son sınıf öğrencilerinin internet bağımlılı̆̆ ölçeğinin boyutlarından yoksunluk, kontrol güçlüğü, işlevsellikte bozulma, sosyal izolasyon ve internet bağımlılık ölçeğinin genelinde cinsiyete göre anlamlı bir farklılaşma görülmektedir $(p<0.05)$.

\section{Öğrencilerin Anne Mesleklerine İlişkin Bulgular}

Tablo 7. Anne Meslekleri ile İnternet Bağımlılı̆̆ı Arasındaki İlişki (ANOVA)

\begin{tabular}{|c|c|c|c|c|c|c|c|}
\hline Boyutlar & & $\begin{array}{l}\text { Kareler } \\
\text { Toplamı }\end{array}$ & $s d$ & $\begin{array}{c}\text { Kareler } \\
\text { Ortalaması }\end{array}$ & $\mathbf{F}$ & $p$ & $\begin{array}{c}\text { Anlaml } \\
\text { Fark } \\
\text { (LSD) }\end{array}$ \\
\hline \multirow{3}{*}{ 1-Yoksunluk } & Gruplar Arası & 2.27 & 3 & .759 & .91 & .434 & \\
\hline & Grup İçi & 2330.58 & 2804 & .831 & & & ------ \\
\hline & Toplam & 2332.86 & 2807 & & & & \\
\hline \multirow{3}{*}{$\begin{array}{l}\text { 2-Kontrol } \\
\text { Güçlüğ̈̈u }\end{array}$} & Gruplar Arası & 2.04 & 3 & .682 & .89 & .442 & \\
\hline & Grup İçi & 2132.86 & 2804 & .761 & & & ------ \\
\hline & Toplam & 2134.91 & 2807 & & & & \\
\hline \multirow{3}{*}{$\begin{array}{l}\text { 3-İşlevsellikte } \\
\text { Bozulma }\end{array}$} & Gruplar Arası & 5.87 & 3 & 1.95 & 2.43 & .063 & \\
\hline & Grup İçi & 2258.83 & 2804 & .806 & & & ------ \\
\hline & Toplam & 2264.71 & 2807 & & & & \\
\hline \multirow{3}{*}{$\begin{array}{c}\text { 4- Sosyal } \\
\text { İzolasyon }\end{array}$} & Gruplar Arası & 14.57 & 3 & 4.85 & 6.72 & $.000^{*}$ & $1-4$ \\
\hline & Grup İçi & 2026.25 & 2804 & .723 & & & $2-3$ \\
\hline & Toplam & 2040.83 & 2807 & & & & \\
\hline 5-İnternet & Gruplar Arası & 2.78 & 3 & .930 & 1.60 & .185 & \\
\hline Bağımlılık & Grup İçi & 1620.74 & 2804 & .578 & & & ------ \\
\hline Ölçeği (Genel) & Toplam & 1623.55 & 2807 & & & & \\
\hline
\end{tabular}

Tablo 7 incelendiğinde, gruplar arasında yoksunluk, kontrol güçlüğü, işlevsellikte bozulma boyutunda ve internet bağımlılık ölçeği genelinde anlamlı farklılaşma görülmemektedir(p>0.05). Sosyal izolasyon boyutunda anlamlı farklılaşma görülmektedir $(\mathrm{p}<0.05)$.

\section{Öğrencilerin Baba Mesleklerine İlişkin Bulgular}

Tablo 8. Baba Meslekleri ile İnternet Bağımlılığı Arasındaki İlişki (ANOVA)

\begin{tabular}{|c|c|c|c|c|c|c|c|}
\hline Boyutlar & & $\begin{array}{l}\text { Kareler } \\
\text { Toplamı }\end{array}$ & $s d$ & $\begin{array}{c}\text { Kareler } \\
\text { Ortalaması }\end{array}$ & $\mathbf{F}$ & $p$ & $\begin{array}{c}\text { Anlamlı } \\
\text { Fark } \\
\text { (LSD) }\end{array}$ \\
\hline \multirow{3}{*}{ 1-Yoksunluk } & Gruplar Arası & 21.57 & 4 & 5.39 & 6.54 & $.000^{*}$ & $1-2,5$ \\
\hline & Grup İçi & 2311.29 & 2803 & .825 & & & $2-3$ \\
\hline & Toplam & 2332.86 & 2807 & & & & $3-5$ \\
\hline \multirow{3}{*}{ 2-Kontrol Güiçlüğüu } & Gruplar Arası & 5.33 & 4 & 1.33 & 1.75 & .135 & \\
\hline & Grup İçi & 2129.57 & 2803 & .760 & & & ----- \\
\hline & Toplam & 2134.91 & 2807 & & & & \\
\hline \multirow{3}{*}{$\begin{array}{l}\text { 3-İşlevsellikte } \\
\text { Bozulma }\end{array}$} & Gruplar Arası & 2.28 & 4 & .572 & .70 & .586 & ----- \\
\hline & Grup İçi & 2262.42 & 2803 & .807 & & & \\
\hline & Toplam & 2264.71 & 2807 & & & & \\
\hline \multirow{3}{*}{ 4-Sosyal İzolasyon } & Gruplar Arası & 7.90 & 4 & 1.97 & 2.72 & $.028^{*}$ & $1-5$ \\
\hline & Grup İçi & 2032.92 & 2803 & .725 & & & \\
\hline & Toplam & 2040.83 & 2807 & & & & \\
\hline 5-İnternet & Gruplar Arası & 2.34 & 4 & .587 & 1.01 & .398 & $\begin{array}{l}--- \\
---\end{array}$ \\
\hline Bağımlılık Ölçeği & Grup İçi & 1621.18 & 2803 & .578 & & & \\
\hline (Genel) & Toplam & 1623.53 & 2807 & & & & \\
\hline
\end{tabular}


Tablo 8 incelendiğinde, gruplar arasında kontrol güçlüğü, işlevsellikte bozulma boyutlarında ve internet bağımlılık ölçeğinin genelinde anlamlı farklılaşma görülmemektedir(p>0.05). Yoksunluk ve sosyal izolasyon boyutlarında anlamlı farklılaşma görülmektedir $(\mathrm{p}<0.05)$.

\section{Öğrencilerin Aile Aylık Gelir Durumuna İlişkin Bulgular}

Tablo 9. Aile Aylık Gelir Durumu ile İnternet Bağımlılığı Arasındaki İlişki (ANOVA)

\begin{tabular}{|c|c|c|c|c|c|c|c|}
\hline Boyutlar & & $\begin{array}{c}\text { Kareler } \\
\text { Toplamı }\end{array}$ & $s d$ & $\begin{array}{c}\text { Kareler } \\
\text { Ortalaması }\end{array}$ & $\mathbf{F}$ & $p$ & $\begin{array}{c}\text { Anlamlı } \\
\text { Fark } \\
\text { (LSD) }\end{array}$ \\
\hline \multirow{3}{*}{ 1-Yoksunluk } & Gruplar arası & 44.20 & 3 & 14.7 & 18.1 & $.000 *$ & $1-2,3,4$ \\
\hline & Grup İçi & 2288.65 & 2804 & .816 & & & $2-3$ \\
\hline & Toplam & 2332.86 & 2807 & & & & \\
\hline \multirow{3}{*}{$\begin{array}{l}\text { 2-Kontrol } \\
\text { Güçlüğüu }\end{array}$} & Gruplar Arası & 13.11 & 3 & 4.37 & 5.7 & $.001^{*}$ & $1-2,3,4$ \\
\hline & Grup İçi & 2121.79 & 2804 & .757 & & & \\
\hline & Toplam & 2134.91 & 2807 & & & & \\
\hline \multirow{3}{*}{$\begin{array}{l}\text { 3-İşlevsellikte } \\
\text { Bozulma }\end{array}$} & Gruplar Arası & 2.16 & 3 & .72 & .89 & .443 & $\begin{array}{ll}--- \\
---\end{array}$ \\
\hline & Grup İçi & 2262.54 & 2804 & .807 & & & \\
\hline & Toplam & 2264.71 & 2807 & & & & \\
\hline \multirow{3}{*}{$\begin{array}{l}\text { 4-Sosyal } \\
\text { İzolasyon }\end{array}$} & Gruplar Arası & 4.86 & 3 & 1.62 & 2.2 & .082 & $\begin{array}{l}--- \\
---\end{array}$ \\
\hline & Grup İçi & 2035.96 & 2804 & .726 & & & \\
\hline & Toplam & 2040.83 & 2807 & & & & \\
\hline 5-İnternet & Gruplar Arası & 4.84 & 3 & 1.61 & 2.7 & $.039 *$ & $1-3,4$ \\
\hline Bağımlılık & Grup İçi & 1618.68 & 2804 & .577 & & & \\
\hline Ölçeği (Genel) & Toplam & 1623.53 & 2807 & & & & \\
\hline
\end{tabular}

Tablo 9 incelendiğinde, gruplar arasında, işlevsellikte bozulma ve sosyal izolasyon boyutlarında anlamlı farklılaşma görülmemektedir ( $p>0.05)$. Yoksunluk, kontrol güçlüğü ve internet bağımlılık ölçeğinin genelinde anlamlı farklılaşma görülmektedir $(\mathrm{p}<0.05)$.

\section{Öğrencilerin İlgilenilen Spor Dalına İlişkin Bulgular}

Tablo 10. İlgilenilen Spor Dalı ile İnternet Bağımlılığı Arasındaki İlişki

\begin{tabular}{|c|c|c|c|c|c|c|c|}
\hline Boyutlar & $\begin{array}{c}\text { Bir spor dalı } \\
\text { ile ilgileniyor } \\
\text { musunuz? }\end{array}$ & $\mathbf{N}$ & $\overline{\mathbf{x}}$ & SS & $s d$ & $t$ & $p$ \\
\hline 1-Yoksunluk & $\begin{array}{l}\text { Evet } \\
\text { Hayır }\end{array}$ & $\begin{array}{c}1867 \\
941\end{array}$ & $\begin{array}{l}2.44 \\
2.54\end{array}$ & $\begin{array}{l}0.88 \\
0.96\end{array}$ & 2806 & -2.68 & $.007^{*}$ \\
\hline 2-Kontrol Güçlüğü & $\begin{array}{l}\text { Evet } \\
\text { Hayır }\end{array}$ & $\begin{array}{c}1867 \\
941\end{array}$ & $\begin{array}{l}1.99 \\
2.10\end{array}$ & $\begin{array}{l}0.86 \\
0.89\end{array}$ & 2806 & -3.02 & $.003^{*}$ \\
\hline $\begin{array}{l}\text { 3-İşlevsellikte } \\
\text { Bozulma }\end{array}$ & $\begin{array}{c}\text { Evet } \\
\text { Hayır }\end{array}$ & $\begin{array}{c}1867 \\
941 \\
\end{array}$ & $\begin{array}{l}1.89 \\
1.98 \\
\end{array}$ & $\begin{array}{l}0.89 \\
0.90 \\
\end{array}$ & 2806 & -.63 & $.014^{*}$ \\
\hline 4-Sosyal İzolasyon & $\begin{array}{l}\text { Evet } \\
\text { Hayır }\end{array}$ & $\begin{array}{c}1867 \\
941\end{array}$ & $\begin{array}{l}1.81 \\
1.83\end{array}$ & $\begin{array}{l}0.85 \\
0.84\end{array}$ & 2806 & -2.58 & .525 \\
\hline $\begin{array}{l}\text { 5-İnternet Bağımlılık } \\
\text { Ölçeği (Genel) }\end{array}$ & $\begin{array}{l}\text { Evet } \\
\text { Hayır }\end{array}$ & $\begin{array}{c}1867 \\
941\end{array}$ & $\begin{array}{l}2.03 \\
2.11\end{array}$ & $\begin{array}{l}0.75 \\
0.77\end{array}$ & 2806 & -2.68 & $.010^{*}$ \\
\hline
\end{tabular}

Tablo 10 incelendiğinde, sosyal izolasyon boyutunda anlamlı farklılaşma görülmemektedir (p<0.05). İnternet bağımlılık ölçeğinin genelinde ve ölçeğin yoksunluk, kontrol güçlüğü ve işlevsellikte 
bozulma boyutlarında bir spor dalı ile ilgilenenlerle ilgilenmeyenler arasında anlamlı farklılaşma görülmektedir $(\mathrm{p}<0.05)$.

\section{Öğrencilerin Bir Müzik Aleti Çalması Durumuna İlişkin Bulgular}

Tablo 11. Öğrencilerin Bir Müzik Aleti Çalması ile İnternet Bağımlılığı Arasındaki İlişki

\begin{tabular}{|c|c|c|c|c|c|c|c|}
\hline Boyutlar & $\begin{array}{l}\text { Bir müzik } \\
\text { aleti çalıyor } \\
\text { musunuz? }\end{array}$ & $\mathbf{N}$ & $\overline{\mathbf{x}}$ & SS & $s d$ & $t$ & $p$ \\
\hline \multirow{2}{*}{ 1-Yoksunluk } & Evet & 1023 & 2.39 & 0.86 & \multirow{2}{*}{2806} & \multirow{2}{*}{-3.70} & \multirow{2}{*}{$.000^{*}$} \\
\hline & Hayır & 1785 & 2.52 & 0.93 & & & \\
\hline \multirow{2}{*}{ 2-Kontrol Güçlüğü } & Evet & 1023 & 1.91 & 0.80 & \multirow{2}{*}{2806} & \multirow{2}{*}{-5.30} & \multirow{2}{*}{$.000^{\circ}$} \\
\hline & Hayır & 1785 & 2.09 & 0.90 & & & \\
\hline \multirow{2}{*}{$\begin{array}{l}\text { 3-İşlevsellikte } \\
\text { Bozulma }\end{array}$} & Evet & 1023 & 1.81 & 0.83 & \multirow{2}{*}{2806} & \multirow{2}{*}{-4.74} & \multirow{2}{*}{$.000^{\circ}$} \\
\hline & Hayır & 1785 & 1.98 & 0.92 & & & \\
\hline \multirow{2}{*}{ 4-Sosyal İzolasyon } & Evet & 1023 & 1.70 & 0.76 & \multirow{2}{*}{2806} & \multirow{2}{*}{-5.79} & \multirow{2}{*}{$.000^{*}$} \\
\hline & Hayır & 1785 & 1.89 & 0.89 & & & \\
\hline \multirow{2}{*}{$\begin{array}{l}\text { 5-İnternet Bağımlılık } \\
\text { Ölçeği (Genel) }\end{array}$} & Evet & 1023 & 1.95 & 0.69 & \multirow{2}{*}{2806} & \multirow{2}{*}{-5.66} & \multirow{2}{*}{$.000^{*}$} \\
\hline & Hayır & 1785 & 2.12 & 0.78 & & & \\
\hline
\end{tabular}

Tablo 11 incelendiğinde, internet bağımlılık ölçeğinin genelinde ve ölçeğin boyutlarından yoksunluk, kontrol güçlüğü, işlevsellikte bozulma, sosyal izolasyon boyutlarında, herhangi bir müzik aleti çalanlar ile çalmayanlar arasında anlamlı farklılaşma görülmektedir $(\mathrm{p}<0.05)$.

\section{Sonuç ve Tartışma}

Araştırmada katılımcıların \%9.7'si bağımlı grupta yer aldığı tespit edilmiştir. Yapılan literatür taramasında; Günüç (2009) araştırmasında, örneklemin \%10.1'ini internet bağımlısı, \%26.4'ünü risk grubu, \%29.4'ünü eşik grubu ve \%34.1'ini bağımlı olmayan grupta bulmuştur. Aydemir (2018), örneklemin \%14.1'ini bağımlı grupta, \%42.6'sını risk grubunda ve \%43.3'ünü bağımlı olamayan grupta bulmuştur. Çınar (2017), örneklemin \%15.2'sini bağımlı grupta, \%38.9'unu risk grubunda, \%45.9'unu bağımlı olmayan grupta bulmuştur. Demirtaş (2017), katılımcıların \%3.2'sini patolojik internet bağımlılı̆̆ grubunda, \%30.5'ini sinırlı semptomatik grupta ve \%66.3'ünü asemptomatik grupta bulmuştur. Köksal (2015) da araştırmasında internet bağımlılık düzeyi yüksek katılımcı oranını \%3.7, muhtemel internet bağımlısı grubunu \%13, internet bağımlısı olmaya ılımlı \%33.9 ve internet bağımlılığı riski olmayanları \%49.4 olarak bulmuştur. Döner (2011) ise araştırmasında bağımlı grupta katılımcı olmadığı sonucuna ulaşmıştır. Araştırmalarda internet bağımlılık düzeylerinin farklı çıktığ1 görülmektedir. Bu farklılı̆̆ın sebebi, araştırmaların farklı coğrafi bölgelerde yapılması, sosyoekonomik farklılıklar, kültürel farklılıklar veya internet bağımlılık düzeyinin ölçüm biçimi gibi değişkenlerden kaynaklanmış olabileceğini söyleyebiliriz.

Öğrencilerin öğrenim gördüğü okul kademelerine göre internet bağımlılık düzeyleri arasında farklılaşma görülmemiştir ( $p>0.05$ ). Literatür incelendiğinde, okul kademeleri arasında internet bağımlılı̆̆ını araştıran çok az araştırmacının olduğu sonucuna ulaşılmıştır. Bunlardan; İnan (2010) "İlköğretim II. kademe ve ortaöğretim öğrencilerinde internet bağımlılığı" adlı araştırmasında ilköğretim II. kademe ile ortaöğretim öğrencileri arasında internet bağımlılı̆̆ı düzeyi arasında anlamlı farklılaşma olduğu, farklılaşmanın 8. sınıflar ile 10. sınıflar; 11. sınıflar ile 6, 10 ve 12 . sınıfta öğrenim gören öğrenciler arasında olduğunu tespit etmiştir. Çınar (2017) ise "Illkokul, ortaokul ve lise son sınıf 
öğrencilerinin internet bağımlılık düzeylerinin incelenmesi" adlı çalışmasında lise son sinıf öğrencilerinin internet bağımlılık düzeyini, ilkokul ve ortaokul son sınıf öğrencilerinden yüksek olduğunu tespit etmiştir. Araştırmaya benzer nitelikte, Akdeniz (2018) araştırmasında okul türleri ile internet bağımlılığı arasında anlamlı ilişki tespit etmemiştir. Yapılan araştırmalar incelendiğinde araştırmaların daha çok internet bağımlılığı ile öğrenim gördüğü sınıf düzeyi arasında anlamlı ilişkinin olup olmadığg incelendiği görülmüştür.

İlkokul ve ortaokul son sınıf öğrencilerinin cinsiyete göre internet bağımlılık puan ortalamaları arasında anlamlı farklılaşma olduğu tespit edilmiştir $(\mathrm{p}<0.05)$. Erkek öğrencilerin internet bağımlılık düzeyleri kızlara göre daha yüksek olduğu sonucuna ulaşılmıştır. Erkek öğrencilerin internet bağımlılık düzeyinin, kızlardan daha yüksek olduğunu göstermektedir. Bu durum erkeklerin kızlara göre internet kafelere daha fazla gitmeleri, daha uzun süre internet kafelerde kalabilmeleri, kızların ise erkeklere oranla internet kafelere gitmede ebeveyn baskısına daha fazla maruz kalmaları gibi durumların erkelerin internet bağımlılığının kızlara oranla daha yüksek düzeyde olmasında etkili olduğu söylenebilir. Yapılan literatür taramasında; cinsiyet değişkeni ile internet bağımlılığı arasındaki ilişkiyi araştıran çalışmalar birbirinden farklı sonuçlar içermektedir. Aydemir (2018), Karasu, Bayır ve Çam (2017), Morahan-Martin ve Schumacher (2000), Turan (2017), Demirtaş (2017), Çınar (2017), İşsever (2016) araştırmasında erkeklerin internet bağımlılık düzeyini, kızlara göre daha yüksek bulmuşlardır. $\mathrm{Bu}$ sonuçlar, araştırmada cinsiyet bakımından ulaşılan bulguları desteklemektedir. Bazı araştırmacılarda Doğruluk (2017), Arslan (2017), Kim vd. (2006), Khan, Shabbir ve Rajput (2017), Akdeniz (2018), Medikoğlu (2018) ve Çam (2014) cinsiyet ile internet bağımlılığı arsında anlamlı farklılaşma bulmamışlardır. Çok az sayıdaki araştırmacılar da Beşaltı (2016), Bölükbaş (2003) ve Griffiths (1999) internet bağımlılık düzeyini kızların lehine bulmuşlardır.

Anne eğitim durumu ile internet bağımlılık puan ortalamaları arasında anlamlı farklılaşma görülmemiştir ( $>0.05)$. Alan yazın incelendiğinde, anne eğitim düzeyi ile internet bağımlılığı ile ilgili çok fazla çalışma bulunmamakla beraber araştırmada ulaşılan sonuca benzer; Çınar (2017), Gençer (2017), Medikoğlu (2018), Arslan (2017), İşsever (2016) ve Karakuş (2016) anne eğitim durumları ile internet bağımlılığı arasında manidar bir ilişki olmadığını belirtmişlerdir. İnan (2010), Durak-Batıgün ve Kılıç (2011), Koyuncu vd. (2012) ise anne eğitim durumu yükseldikçe öğrencilerin internet bağımlılık düzeyinin arttığını belirtmiştir. Demetrovics, Szeredi ve Rozsa (2008) ise aile eğitim düzeyinin arttıkça internet bağımlılığının azaldığını tespit etmiştir.

Baba eğitim durumu ile internet bağımlılık puan ortalamaları arasında anlamlı farklılaşma görülmemiştir ( $p>0.05$ ). İnternet bağımlılığı ile baba eğitim düzeyi arasındaki farklılaşmayı inceleyen ve bu konudaki bulgulara paralel olan araştırma sonuçlarına bakıldığında, Günüç (2009) araştırmasında internet bağımlılığı ile baba eğitim durumu arasında anlamlı bir ilişki bulunmadığını belirtmiştir. Dinç'in (2017) lise öğrencilerinde internet bağımlılığı ile bağlanma stilleri ve mizaç özellikleri arasındaki ilişkileri incelediği araştırmasında, baba eğitim durumu ile internet bağımlılığı arasında anlamlı bir farklılaşma tespit etmemiştir. Benzer şekilde, Çınar (2017), Doğan (2013), Akdeniz (2018), İnan (2010) ve Saatçığlu (2016) baba eğitim durumu ile internet bağımlılığı davranışları arasında manidar bir ilişkinin olmadığını belirtmişlerdir. Bu bulgular araştırmada ulaşılan sonucu desteklemektedir. Araştırma bulgularından farklı olarak, Karakuş (2016) araştırmasında baba eğitim seviyesi yükseldikçe internet bağımlılık düzeyinin düştüğünü tespit etmiştir. Tanrıverdi (2012) de internet bağımlılı̆̆ı ve algılanan sosyal destek arasındaki ilişkiyi incelediği araştırmasında internet bağımlılı̆̆ ile baba eğitim durumu arasında anlamlı ilişki bulmuştur. Turan (2017) ise baba eğitim durumu lisans ve üzeri olan öğrencilerin, ortalamanın üzerinde internet bağımlısı olduğunu bulmuştur. 
Anne mesleği ile internet bağımlılık puan ortalamaları arasında anlamlı farklılaşma görülmemiştir ( $p>0.05)$. Alan yazın incelendiğinde, anne mesleği ile internet bağımlılığı arasında ilişkiyi inceleyen çok fazla çalışma bulunmadığı görülmüştür. Çok az sayıdaki araştırmalar incelendiğinde araştırmada ulaşılan sonucu destekler nitelikte, Çınar (2017) ilkokul, ortaokul ve lise son sınıf öğrencilerinin internet bağımlılık düzeyini incelediği araştırmasında anne mesleği ile öğrencilerin internet bağımlılığı arasında anlamlı ilişki bulmamıştır. Günüç (2009) ise araştırmasında anne meslekleri internet bağımlığı arasında anlamlı ilişki bulmazken, anne mesleği çok yüksek oranla ev hanımı olduğunu bulmuştur. Benzer şekilde, Karasu vd. (2017), Tanrıverdi (2012), Doğan (2013) ve Çam (2014) anne meslekleri ile internet bağımlılığı arasında anlamlı ilişki olmadığını tespit etmişlerdir.

Baba mesleği ile internet bağımlılık puan ortalamaları arasında anlamlı farklılaşma görülmemiştir ( $p>0.05)$. Yapılan literatür taramasında: Çınar (2017) 2611 öğrenci üzerinde yapmış olduğu araştırmasında, baba mesleğini çoğunlukla memur olarak bulurken, baba meslekleri ile internet bağımlılığı arsında anlamlı farklılaşma tespit etmemiştir. Benzer şekilde, Karasu vd. (2017), Tanrıverdi (2012), Doğan (2013), Akdeniz (2018) ve Çam (2014) da baba meslekleri ile internet bağımlılı̆̆ı arasında anlamlı ilişki olmadığını bulmuşlardır. Bu bulgular araştırmada ulaşılan sonuçları desteklemektedir. Araştırmada ulaşılan sonuçlardan farklı olarak, Günüç (2009), farklı illerdeki liselerde öğrenim görmekte olan ergenler üzerinde yapmış olduğu araştırmasında baba mesleği ile internet bağımlılığı arasında ilişki bulunmuş ve babası "asker-polis" ile "öğretmen-akademisyen-mühendis" olan ergenlerin bağımlılık düzeyleri daha yüksek olduğu sonucuna ulaşmıştır.

Ailenin aylık geliri ile internet bağımlılık puan ortalamaları arasında anlamlı farklılaşma görülmüştür $(\mathrm{p}<0.05)$. Aile aylık geliri 3001- $4500 \mathrm{TL}$ arasında olan öğrencilerin internet bağımlılık düzeyi yüksek bulunmuştur. Orta gelir durumuna sahip öğrencilerin, internetin ucuz ve ulaşılabilir olmasından dolayı internete bağımlı oldukları şeklinde yorumlanabilir. Örneklemdeki ailelerin gelir düzeylerinin ağırlıklı olarak 1500 TL ve Altı olduğu görülmüş olup, ağırlıklı olarak aile gelir düzeyi arttıkça internet bağımlılık düzeyinin de arttığı gözlenmiştir. Benzer şekilde çalışmalara bakıldığında, Günüç (2009), Çetinkaya (2013), Çam (2014) araştırmasında geliri yüksek olan ailelerde internet bağımlılık düzeyini daha yüksek bulmuştur. Aslanbay (2006) ve Aslan-Üçkardeş (2010) ise aile gelir düzeyi arttıkça öğrencilerin internet bağımlılığına yatkınlığının arttığını belirtmişlerdir. Bayhan (2011) da çalışmasında internet bağımlılı̆̆ı ile ekonomik gelir arasında doğrudan bir ilişki olduğunu ve ekonomik gelir yükseldikçe bilgisayar ve evde internet bağlantısı oranı artmakta olduğu sonucuna ulaşmıştır. Alan yazın incelendiğinde, elde edilen bulguların aksine çalışmalara da rastlanmaktadır. Çınar (2017), ilkokul, ortaokul ve lise son sınıf öğrencilerinin internet bağımlılık düzeyini incelediği araştırmasında aile gelir durumu ile öğrencilerin internet bağımlılı̆̆ı arasında anlamlı ilişki bulmamıştır. Bunun yanında, Karasu vd. (2017), Arslan (2017), Akdeniz (2018), Özdemir (2016) ve Karakuş (2016) da araştırmalarında ailenin aylık gelir durumu ile internet bağımlılığı arasında anlamlı farklılaşma bulmamışlardır.

Herhangi bir spor dalı ile ilgilenme-ilgilenmeme durumuyla internet bağımlılık puan ortalamaları arasında anlamlı farklılaşma olduğu bulunmuştur $(\mathrm{p}<0.05)$. Bir spor dalı ile ilgilenmeyenlerin internet bağımlılık düzeyi ilgilenenlerden daha yüksek düzeyde olduğu görülmektedir. Spor yapan öğrencilerin internet bağımlılık düzeyi, yapmayanlardan düşük çıkması beklenen bir sonuç diyebiliriz. Spor yapan öğrencilerin boş vakitlerinde internet başında zaman geçirmeyip, herhangi bir spor etkinliği ile zaman geçirdiklerinden internet bağımlılık düzeylerinin düşük olabileceğini söyleyebiliriz. Yapılan literatür taramasında araştırmadaki sonuca benzer sonuca ulaşan, Canoğulları (2014) spor yapan öğrencilerin internet bağımlılık düzeyini düşük bulmuştur. 
Makas (2008) ise araştırmasında katılımcıların çoğunluğu internet olmasaydı boş zamanını spor yapmakla geçireceğini belirtmiştir. Araştırmada ulaşılan sonucun tersi nitelikte, Alaçam (2012) düzenli olarak spor yapan öğrencilerin internet bağımlılık düzeyini, düzenli olarak spor yapmayan öğrencilere göre anlamlı düzeyde daha yüksek bulmuştur. Khan vd. (2017) ise araştırmalarında internet bağımlılığının toplam puanı ve sıklığı fiziksel aktivite olmayan öğrencilerde daha yüksek çıkmış ve fiziksel aktiviteyle ters orantılı olduğuna ulaşmışlardır. Canan (2010), Yar (2012), Yıldırım (2016), Özdemir (2016) ise araştırmalarında internet bağımlılığı ile spor etkinliğine katılanlarla katılmayanlar arasında anlamlı farklılaşma bulmamışlardır.

Bir müzik aleti çalma-çalmama durumu ile internet bağımlılık puan ortalamaları arasında anlamlı farklılaşma olduğu bulunmuştur $(\mathrm{p}<0.05)$. Müzik aleti çalmayan öğrencilerin, müzik aleti çalanlardan daha yüksek düzeyde internet bağımlılığı gösterdikleri sonucuna ulaşılmıştır. Herhangi bir müzik aleti çalmayan öğrenciler çalanlara oranla internet başında daha fazla zaman harcadıklarından (film indirme, izleme, internette sohbet gibi.) çevrelerindeki insanlara (anne, baba, kardeş, arkadaş gibi.) daha az zaman ayırmakta oldukları ve sosyal çevrelerinden uzaklaştıkları söylenebilir. Herhangi bir müzik aleti çalan öğrencilerin ise fiziksel ve zihinsel olarak rahatladıkları için müzikten arta kalan zamanlarında internete yönelmek yerine sosyal çevreleriyle zaman geçirmelerine ve çevreleriyle daha iyi ilişki kurabildikleri şeklinde yorumlanabilir. Literatür incelendiğinde, araştırmaların daha çok interneti müzik dinlemek için kullanılıp kullanılmadığı üzerine incelendiğini görmekteyiz. Aslanbay (2006) araştırmasında internet bağımlılarının interneti en çok müzik ve film indirme, e-posta, sohbet ve arkadaş bulma amacı ile kullandıklarını belirtmiştir. Bayraktar ve Gün (2006) ise araştırmasında internet kullanıcılarının interneti en çok öğrenme ve bilgi edinme amacı ile değil de müzik dinleme, nette gezinme ve sohbet amaçlı kullandıklarını belirtmişlerdir. Akdeniz (2018) araştırmasında katılımcılar interneti \%4,7'sinin müzik dinleme amaçlı kullandıklarını belirtmiştir. Araştırma bulgularını destekler nitelikte araştırmalara da rastlamak mümkündür. Canoğulları (2014) internet bağımlılık düzeyi düşük olan ergenlerde kendilerine ait zamanda kitap okuduklarını, aileleriyle ve arkadaşlarıyla vakit geçirdiklerini, televizyon seyrettiklerini, müzik dinlediklerini ve spor yaptıklarını tespit etmiştir. Makas (2008) ise araştırmasında katılımcıların internet olmasaydı boş zamanını müzik aleti çalmakla geçireceğini belirtmiştir. Araştırmanın bulgusunun tersi niteliğinde, Kaya (2011) araştırmasında müzik dinleyenlerin internet bağımlılık düzeyini yüksek bulmuştur. Öztürk ve Kaymak-Özmen (2011) ise araştırmasında, internette müzik dinleyenlerin problemli internet kullanmaya eğilimli olduklarını tespit etmişlerdir. Kim ve Kim (2002), internet bağımlısı olan kullanıcıların, film-müzik sitelerinde daha çok zaman harcadıklarını tespit etmişlerdir.

Araştırma sonuçlarına dayalı olarak şu öneriler sunulabilir;

1. Araştırmada internet bağımlısı olanların oranı (\%9.7) önemsenmeyecek kadar düşük değildir. İnternet bağımlılığı puanının \%9.7 çıkmasına etki eden sebepler araştırılmalı ve internet bağımlılığı hakkında daha bilinçli internet kullanıcıları yetiştirilmelidir.

2. Bu araştırma ilkokul ve ortaokul son sınıfta okuyan öğrenciler üzerinde yapılmıştır. Yapılacak daha sonraki çalışmalarda ortaöğretim ve üniversite öğrencileri de ele alınarak, internet bağımlılı̆̆ı durumunun diğer öğretim kademelerini temsil eden örneklemlerle çalışılmasının, sonuçları genelleyebilme açısından yararlı olacağı düşünülmektedir.

3. Erkek öğrencilerin internet bağımlılık düzeyi yüksek bulunmuştur. Erkek çocuğu olan ebeveynler, çocuklarının internet kullanımında daha kontrollü olması konusunda bilinçlendirilmeli, 
Millı̂ Eğitim Bakanlığı ve Gelişim Uzmanları tarafından erkek öğrencilerin internet bağımlılık düzeyini düşürmeye yönelik önleyici çalışmalar yapılmalıdır.

4. Orta gelir durumuna sahip ailelere, çocuklarını internetin zararlarından korumaya yönelik çalışmalar (internetin zararlı yönlerini gösteren broşürler, reklamlar gibi.) yapılabilir ve internetin olumlu ve olumsuz yanları, internetin bilinçli ve sağlıklı kullanımı, internet kullanımın tehlikeli ve riskli yönleri hakkında bilgilendirici seminerler, toplantılar düzenlenebilir.

5. Spor yapan öğrencilerin internet bağımlılık düzeyi düşük bulunmuştur. Öğrencilerin, internete gereksiz yönelmelerini engellemek için okullara ve mahalle aralarına spor yaşam alanları (futbol, basketbol, voleybol sahaları, tenis kortu, yüzme havuzu gibi.) yapılmalı ve öğrenciler boş vakitlerinde spor yapmaya yönlendirilmelidir.

6. Öğrencilerin enerjilerini doğru yönde kullanabilmesi için okulların fiziki şartları iyileştirilmelidir. Özellikle müzikle alakalı faaliyetlere yer verilmeli ve öğrencilerin bu imkânlardan en üst seviyede faydalanmalarını sağlayacak öğrenme atölyeleri oluşturulup internet bağımlılı̆̆ının önlenmesi ya da en aza indirilmesi sağlanmalıdır.

\section{Kaynakça}

Akdeniz, B. (2018). 14 - 16 yaş aralı̆̆ındaki ergenlerin bağlanma stilleri, gözlerden zihin okuma becerileri ve ruhsal sorunları ile internet bağ̆ımlılığı düzeyleri arasındaki ilişkinin incelenmesi:İstanbul ili örneği. Yüksek Lisans Tezi. Ondokuz Mayıs Üniversitesi Sosyal Blimler Enstitüsü, Samsun.

Aksoy, F. (2016). Ergenlerde internet bağımlılığı ile şema mekanizmaları ve baş etme becerileri arasındaki ilişkinin incelenmesi. Yüksek Lisans Tezi. Üsküdar Üniversitesi Sosyal Bilimler Enstitüsü, İstanbul.

Alaçam, H. (2012). Denizli bölgesi üniversite öğrencilerinde internet bağımlllığının görülme sıklı̆̆ı ve yetişkin dikkat eksikliği hiperaktivite bozukluğu ile ilişkisi. Uzmanlık Tezi. Pamukkale Üniversitesi Tıp Fakültesi, Denizli.

Arısoy, Ö. (2009). İnternet bağımlılığı ve tedavisi. Psikiyatride Güncel Yaklaşımlar, 1(1), 55-67.

Arslan, G. (2017). Anne babası boşanmış ve boşanmamış olan ergenlerin internet bağımlllı̆̆ı düzeylerinin incelenmesi. Yüksek Lisans Tezi. İstanbul Ticaret Üniversitesi Sosyal Bilimler Enstitüsü, İstanbul.

Aslan-Üçkardeş, E. (2010). Mersin Üniversitesi öğrencileri arasında internet bağımlılı̆̆ının değerlendirilmesi. Uzmanlık Tezi. Mersin Üniversitesi Tıp Fakültesi, Mersin.

Aslanbay, M. (2006). A compulsive consumption: Internet use addictiontendency the case of Turkish high school students. Yüksek Lisans Tezi. Marmara Üniversitesi Sosyal Bilimler Enstitüsü, İstanbul.

Aydemir, H. (2018). Examining the internet addiction levels of high school senior students. Journal of Education and Training Studies, 6(4), 17-25.

Balcı, Ş. ve Gülnar, B. (2009). Üniversite öğrencileri arasında internet bağımlılığı ve internet bağımlılarının profili. Selçuk Üniversitesi İletişim Fakültesi Akademik Dergisi, 6(1), 5-22.

Batıgün, A.D. ve Hasta, D. (2010). İnternet bağımlılığı: Yalnızlık ve kişiler arası ilişki tarzları açısından bir değerlendirme. Anadolu Psikiyatri Dergisi, 11, 213-219.

Bayhan, V. (2011). Lise öğrencilerinde internet kullanma alışkanlığı ve internet bağımlılığı (Malatya uygulaması). Akademik Bilişim Konferansı (s. 917-924). Malatya: İnönü Üniversitesi. 
Bayraktar, F. (2013). İnternet ve ergen gelişimi. Kalkan, M. ve Kaygusuz, C. (Ed.), İnternet bağımlılı̆̆ı, sorunlar ve çözümler içinde (s. 3-4). Ankara: Anı.

Bayraktar, F. ve Gün, Z. (2006). Incidence and correlates of Internet usage among adolescents in North Cyprus. CyberPsychology \& Behavior, 10(2), 191-197.

Beşaltı, M. (2016). Ergenlerde internet bağımlılığı ve kişilik özelliklerinin bazı sosyodemografik özelliklere göre incelenmesi. Yüksek Lisans Tezi. Gaziantep Üniversitesi Eğitim Bilimleri Enstitüsü, Gaziantep.

Bölükbaş, K. (2003). Internet cafeler ve internet bağımlılığı üzerine sosyolojik bir araştırma: Diyarbakır örneği. Yüksek Lisans Tezi. Dicle Üniversitesi Sosyal Bilimler Enstitüsü, Diyarbakır.

Brenner, V. (1997). Psychology of computer use: XLVII. Parameters of internet use, abuse and addiction: The first 90 days of the Internet Usage Survey. Psychological Reports, 80(3), 879-882.

Canan, F. (2010). Üniversite öğrencilerinde internet bağımlılı̆̆ı, disosiyatif belirtiler ve sosyodemografik özellikler arasındaki ilişki. Uzmanlık Tezi. Düzce Üniversitesi Tıp Fakültesi, Düzce.

Canoğulları, Ö. (2014). İnternet bağımlılık düzeyleri farklı ergenlerin cinsiyetlerine göre psikolojik ihtiyaçları, sosyal kaygıları ve anne baba tutum algılarının incelenmesi. Yüksek Lisans Tezi. Çukurova Üniversitesi Sosyal Bilimler Enstitüsü, Adana.

Ceyhan, E. (2016). İnternet bağımlılı̆̆ıın bağlanma sitilleri ve duygu düzenlemeyle ilişkisi. Yüksek Lisans Tezi. Yüzüncü Yıl Üniversitesi Eğitim Bilimleri Enstitüsü, Van.

Ceylan, Z., Gürsev, S. ve Bulkan, S. (2017). İki aşamalı kümeleme analizi ile bireysel emeklilik sektöründe müşteri profilinin değerlendirilmesi. Bilişim Teknolojileri Dergisi, 10(4), 475-485.

Chen, K., Tarn, J.M. ve Han, B.T. (2004). Internet dependency: It's impact on online behavioral patterns in e-commerce. Humen Systems Management, 23, 49-58.

Chen, S.H. ve Chou, C. (1999). Development of Chinese Internet Addiction Scale in Taiwan. The 107th American Psychology Annual Convention'da sunulmuş poster bildiri, Boston, ABD.

Çakır, Ö., Horzum, M.B. ve Ayas, T. (2013). İnternet bağımlılı̆̆ının tanımı ve tarihçesi. M. Kalkan ve C. Kaygusuz, İnternet Bağımlılı̆̆ı Sorunlar ve Çözümler içinde (s. 1-16). Ankara: Anı.

Çam, H.H. (2014). Adölesanlarda internet bağımlılığı prevalansı ile psikopatolojik semptomlar ve obezite arasındaki ilişkinin incelenmesi. Doktora Tezi. Cumhuriyet Üniversitesi Sağlık Bilimleri Enstitüsü, Sivas.

Çetinkaya, M. (2013). İlköğretim öğrencilerinde internet bağımlılğının incelenmesi. Yüksek Lisans Tezi. Dokuz Eylül Üniversitesi Eğitim Bilimleri Enstitüsü, İzmir.

Çınar, M. (2017). Illkokul, ortaokul ve lise son sınıf öğrencilerinin internet bağımlılık düzeylerinin incelenmesi. Yüksek Lisans Tezi. İnönü Üniversitesi Eğitim Bilimleri Enstitüsü, Malatya.

Demetrovics, Z., Szeredi, B. ve Rozsa, S. (2008). The three-foctors model of internet addiction: The Development of problematic internet use questionnaire. Behavior Research Methots, 563-574.

Demirtaş, Ö.Ö. (2017). Dikkat eksikliği ve hiperaktivite bozukluğu olan ergenlerde internet bağımlilığının prevalansı ve prediktörleri. Uzmanlık Tezi. İstanbul Üniversitesi İstanbul Tıp Fakültesi, İstanbul.

Dinç, M. (2017). Lise öğrencilerinde özgül internet bağımlılı̆̆ının bağlanma stilleri ve mizaç özellikleri açısından incelenmesi. Doktora Tezi. Marmara Üniversitesi Eğitim Bilimleri Enstitüsü, İstanbul. 
Dinçer, E. (2006). Veri madenciliğinde k-means algoritması ve tıp alanında uygulanması. Yüksek Lisans Tezi. Kocaeli Üniversitesi Fen Bilimleri Enstitüsü, Kocaeli.

Doğan, A. (2013). Internet bă̆ımlılı̆̆ı yaygınlı̆̆ı. Yüksek Lisans Tezi. Dokuz Eylül Üniversitesi Eğitim Bilimleri Enstitüsü, İzmir.

Doğruluk, S. (2017). Öğretmen adaylarının sosyal medya kullanım alışkanlıkları ile internet bağımlılıkları arasındaki ilişki. Yüksek Lisans Tezi. Kahramanmaraş Sütçü İmam Üniversitesi Sosyal Bilimler Enstitüsü, Kahramanmaraş.

Döner, C. (2011). İlköğretim öğrencilerinde internet bağımlılı̆̆ının farklı değişkenlere göre incelenmesi. Yüksek Lisans Tezi. Ankara Üniversitesi Eğitin Bilimleri Enstitüsü, Ankara.

Durak-Batıgün, A. ve Kılıç, N. (2011). İnternet bağımlılı̆̆ı ile kişilik özellikleri sosyal destek, psikolojik belirtiler ve bazı sosyo-demografik değişkenler arasındaki ilişkiler. Türk Psikoloji Dergisi, 26(67), $1-10$.

Ganesh, A., Pragyakumari, D., Ramsudarsan, N., Rajkumar, M., Shyam, S. ve Balaji, S.K. (2017). SelfReported behaviour about internet addiction among medical and paramedical students. Journal of Clinical and Diagnostic Research, 11(10), 10-13.

Gençer, H. (2017). Ortaokul öğrencilerinde internet bă̆ımlılı̆̆ı ve siber zorbalık davranışları ile ilişkili değişkenlerin incelenmesi. Yüksek Lisans Tezi. Cumhuriyet Üniersitesi Eğitim Bilimleri Enstitüsü, Sivas.

Gençer, S.L. (2011). Ortaöğretim öğrencilerinin internet bağımlılık durumlarının internet kullanım profilleri ve demografik özelliklere göre farklılıklarının incelenmesi. Yüksek Lisans Tezi. Süleyman Demirel Üniversitesi Fen Bilimleri Enstitüsü, Isparta.

Griffiths, M.D. (1999). Internet addiction: Fact or fiction? The Psychologist: Bulletin of the British Psychological Society, 246-250.

Günüç, S. (2009). Internet bağımlılık ölçeğinin geliştirilmesi ve bazı demografik değişkenler ile internet bă̆ımlılı̆̆ı arasındaki ilişkilerin incelenmesi. Yüksek Lisans Tezi. Yüzüncü Yıl Üniversitesi Sosyal Bilimler Enstitüsü, Van.

İnan, A. (2010). Illköğretim II. kademe ve ortaöğretim öğrencilerinde internet bağımlılı̆̆ı. Yüksek Lisans Tezi. Atatürk Üniversitesi Sosyal Bilimler Enstitüsü, Erzurum.

İşsever, N.K. (2016). İnternet bağımlılı̆̆ının üniversite öğrencilerinde yaygınlı̆̆ının incelenmesi. Yüksek Lisans Tezi. Üsküdar Üniversitesi Sosyal Bilimler Enstitüsü, İstanbul.

Karakuş, Z. (2016). Internet bă̆ımlılık düzeyinin TEOG ders puanları ve bazı değişkenler açısından incelenmesi. Yüksek Lisans Tezi. Çağ Üniversitesi Sosyal Bilimler Enstitüsü, Mersin.

Karasu, F., Bayır, B. ve Çam, H.H. (2017). Üniversite öğrencilerinin internet bağımlılı̆̆ı ile sosyal destek arasındaki ilişkinin incelenmesi. Sosyal Bilimler Dergisi, 7(14), 374-386.

Kaya, A. (2011). Öğretmen adaylarının sosyal ă̆ sitelerini kullanım durumları ve internet bağımlılığı düzeyleri. Yüksek Lisans Tezi. Ege Üniversitesi Fen Bilimleri Enstitüsü, İzmir.

Khan, M.A., Shabbir, F. ve Rajput, T.A. (2017). Effect of gender and physical activity on internet addiction in medical students. Pakistan Journal of Medical Sciences, 33(1), 191-194. 
Kim, K., Ryu, E., Chon, M.Y., Yeun, E.J., Choi, S.Y., Seo, J.S., ... Nam, B.W. (2006). Internet addiction in Korean adolescents and its relation to depression and suicidal ideation: A questionnaire survey. International Journal of Nursing Studies, 43, 185-192.

Kim, S. ve Kim, R. (2002). A study of internet addiction: Status, causes, and remedies-focusing on the alienation factor. International Journal of Human Ecology, 3(1), 1-19.

Koçaş, F. (2017). Mersin'de lise öğrencilerinde sanal iletişim araçlarının kullanımı ve internet bă̆ımlılı̆̆ının uyku kalitesi ile ilişkisinin araştırılması. Uzmanlık Tezi. Mersin Üniveristesi Tıp Fakültesi, Mersin.

Koyuncu, T., Ünsal, A. ve Arslantaş, D. (2012). İlköğretim ve lise öğrencileri arasında internet bă̆ımlılı̆̆ı ve yalnızlık. 15. Ulusal Halk Sağlığı Kongresi'nde sunulmuş bildiri, Uludağ Üniversitesi, Bursa.

Köksal, Y. (2015). İnternet bağımlılığı ile internetten alışveriş ilişkisi üzerine bir incelenme; üniversite öğrencileri uygulaması. Mehmet Akif Ersoy Üniversitesi Sosyal Bilimler Enstitüsü Dergisi, 7(12), 117-130.

Makas, Y. (2008). Lise öğrenimi gören gençlerin internet kullanımının psikososyal durum ile ilişkisi. Yüksek Lisans Tezi. Beykent Üniversitesi Sosyal Bilimler Enstitüsü, İstanbul.

Medikoğlu, O. (2018). İlkokul 4. sını öğrencilerinin internet bağımlılığı düzeylerinin belirlenmesi ve akademik başarıları arasındaki ilişkinin incelenmesi. Yüksek Lisans Tezi. Necmettin Erbakan Üniversitesi Eğitim Bilimleri Enstitüsü, Konya.

Morahan-Martin, J. ve Schumacher, P. (2000). Incidence and correlates of pathological internet use among college students. Computers in Human Behavior, 16(1), 13-29.

Özdemir, G. (2016). Ondokuz Mayıs Üniversitesi Tıp Fakültesi öğrencilerinde internet bağımlılı̆̆ı ve depresyon arasındaki ilişkinin değerlendirilmesi. Uzmanlık Tezi. Ankara Üniversitesi Tıp Fakültesi, Ankara.

Öztürk, E. ve Kaymak-Özmen, S. (2011). Öğretmen adaylarının problemli internet kullanım davranışlarının kişilik tipi, utangaçlık ve demografik değişkenlere göre incelenmesi. Kuram ve Uygulamada Ĕ̆itim Bilimleri, 11(4), 1785-1808.

Reisoğlu, İ., Gedik, N. ve Göktaş, Y. (2013). Öğretmen adaylarının özsaygı ve duygusal zekâ düzeylerinin problemli internet kullanımıyla ilişkisi. Eğitim ve Bilim, 38(170).

Saatçıŏlu, H. (2016). Internet bă̆ımlılı̆̆ı tanısı alan ergenlerin sosyal bilişsel becerilerinin değgerlendirilmesi. Uzmanlık Tezi. Ege Üniversitesi Tıp Fakültesi, İzmir.

Sağat, B. (2017). Dikkat eksikliği ve hiperaktivite bozukluğu olan ergenlerde görülen internet bă̆ımlılı̆̆ının benlik saygısı ile ilişkisi. Uzmanlık Tezi. Işık Üniversitesi Sosyal Bilimler Enstitüsü, İstanbul.

Savaş, S. ve Topaloğlu, N. (2011). Veri madenciliği yöntemi ile GSM şebekelerinin performans analizi. Gazi Üniversitesi Mühendislik-Mimarlık Fakültesi Dergisi, 26(4), 241-251.

Social, W.A. (2018). Digital in 2018: Global overview. https://wearesocial. com/blog/2018/01/global-digitalreport-2018 sayfasından erişilmiştir.

Tanrıverdi, S. (2012). Ortaöğretim öğrencilerinde internet bağımlılı̆̆ı ile algılanan sosyal destek arasındaki ilişkinin incelenmesi. Yüksek Lisans Tezi. Yüzüncü Yıl Üniversitesi Eğitim Bilimleri Enstitüsü, Van.

Turan, F. (2017). Ergenlerde internet bağımlılı̆̆ının anne baba tutumları açısından incelenmesi. Yüksek Lisans Tezi. Üsküdar Üniversitesi Sosyal Bilimler Üniversitesi, İstanbul. 
TÜIKK. (2018). Hanehalkı bilişim teknolojileri kullanım araştırması. TÜiK: http://www.tuik.gov.tr/PreHaberBultenleri.do?id=27819 sayfasından erişilmiştir.

Yar, A. (2012). Ruhsal bozukluğu olan ve olmayan ergenlerde internet bağımlılı̆̆ı yayginlı̆̆ı. Uzmanlık Tezi. Kocaeli Üniversitesi Tıp Fakültesi, Kocaeli.

Yellowlees, P. ve Marks, S. (2007). Problematic internet use or internet addiction? Computers in Human Behavior, 1447-1453.

YEŞILAY. (2017). Bağımlılık nedir? http://www.yesilay.org.tr/tr/bagimlilik/bagimlilik-nedir sayfasından erişilmiştir.

Yıldırım, M.S. (2016). Ergenlerde internet bağımlılı̆̆ının obezite ve benlik saygısı ile ilişkisinin incelenmesi. Yüksek Lisans Tezi. İstanbul Gelişim Üniversitesi Sosyal Bilimler Enstitüsü, İstanbul.

Young, K.S. (1996). Internet addiction: The emergence of a new clinical disorder. CyberPsychology and Behavior, 237-244.

\section{Yazarların Katkı Oranı Beyanı}

Tüm yazarlar, araştırmanın tasarımına, uygulanmasına ve analizine ortak katkıda bulunmuş olup, araştırmanın son halini incelediğini ve onayladığını beyan eder.

\section{Destek ve Teşekkür Beyanı}

$\mathrm{Bu}$ araştırmada herhangi bir kurum, kuruluş ya da kişiden destek alınmamıştır.

\section{Çatışma Beyanı}

Araştırma ile ilgili diğer kişi ve kurumlarla herhangi bir kişisel ve finansal çıar çatışması yoktur.

\section{Etik Bildirim}

$\mathrm{Bu}$ araştırma, 01.01.2020 tarihinden önce yapıldığından etik kurul kararı zorunluluğu yoktur. 